\title{
Students' Attitudes and Their Academic Performance in Nationhood Education
}

\author{
Mohd Mahzan Awang ${ }^{1}$, Abdul Razaq Ahmad ${ }^{1}$, Nora'asikin Abu Bakar ${ }^{2}$, Sayuti Abd Ghani ${ }^{3}$, Asyraf Nadia Mohd \\ Yunus $^{2}$, Mohd Asrul Hery Ibrahim², Jaya Chitra Ramalu ${ }^{2}$, Che Pee Saad ${ }^{4} \&$ Mohd Jasmy Abd Rahman ${ }^{1}$ \\ ${ }^{1}$ Faculty of Education, Universiti Kebangsaan Malaysia, Bangi, Malaysia \\ ${ }^{2}$ Faculty of Applied Science and Foundation Studies, Infrastructure University Kuala Lumpur, Malaysia \\ ${ }^{3}$ National Defence University of Malaysia, Malaysia \\ ${ }^{4}$ Malaysian Islamic University Council, Bangi, Malaysia \\ Correspondence: Mohd Mahzan Awang, Faculty of Education, Universiti Kebangsaan Malaysia, UKM Bangi \\ 43600, Selangor, Malaysia. Tel: 603-8921-6274. E-mail: mohdmahzan@gmail.com
}

Received: September 6, 2013 Accepted: September 26, 2013 Online Published: October 11, 2013

doi:10.5539/ies.v6n11p21

URL: http://dx.doi.org/10.5539/ies.v6n11p21

\begin{abstract}
The main goal of the nationhood education is to instill the sense of loyalty and passion into the nation. In a Malaysian context, several academic subjects at higher education such as Malaysian Studies, Ethnic Relations and National Language have been implemented in order to achieve the goal. Malaysian Study is one of the compulsory courses offered by all private universities in Malaysia that is intended to educate students with national values, patriotism and belongingness to the country. However, past empirical evidence show that many students have a lack of interest to learn such subject. Therefore, the current study investigated contributing factors to students' academic achievement and also examined students' attitudes towards that subject. Using quantitative approach, the current study categorized four main factors namely the suitability and interest in syllabus, being active in class, early preparation and revision, types of enjoyable activities, interest in teaching aids and good class attendance. Using questionnaires and SPSS software as the main tools in this study, the mean score, frequency and percentage were obtained. It is concluded statistically from this study that students' perception of their lecturers play a significant role in determining their learning outcomes in Malaysian Studies, while the lecturers are of the opinion that learning environment is a factor which contributes significantly to the students' achievement in this subject. The current study suggests that the teachers build upon excellent rapport with students and create an attractive and enjoyable environment to get the students to dynamically involve in the classroom activities and learn the Malaysian Studies enthusiastically and efficiently.
\end{abstract}

Keywords: Malaysian studies, nationhood, interests, teaching aids, learning environment, academic performance

\section{Introduction}

Nationhood education is the main priorities by the government all over the world. In the United Kingdom and Australia for instance, nationhood education is recommended to be part of national school curriculum (McKenzie, 1993). In Indonesia, nationhood education is embedded in the official philosophical foundation known as pancasila. In a Malaysian context, the importance of nationhood education can be seen in the national philosophy known as rukunegara and the Constitutional Law. Nationhood education "is important not only for its effects on politics and government, but also in relation to community and voluntary activities, and social and international harmony (McKenzie, 1993)". One of the common strategies to promote good citizens is via Nationhood and Citizenship Education curriculum either at a school level or higher degree level.

Kerr (2005) surveyed 6400 students from 237 secondary schools and 50 colleges, 238 school and college heads and 876 teachers and college tutors in England where the study found that young peoples' development of citizenship dimensions are influenced by a range of interrelated factors and influences including school, family, peer groups, community, teachers, parents, friends and the educational processes. The study also highlighted possible influences of socio-cultural factors on citizenship dimensions among participants. 


\section{Students' Attitudes and Academic Achievement in Nationhood Education}

In Malaysia, nationhood education curriculum is delivered in several subjects including History, Civic Education, Ethnic Relations, General Studies and Malaysian Studies. The Malaysian Private Higher Education Act 1990 posits that it is compulsory for all students to study and pass the Malaysian Studies subject. Due to this regulation, all students in private universities comprising a total number of 323,787 students (Da, 2007) studied Malaysian Studies subject. Irrespective of the importance of this subject for the country, empirical evidence shows that most students lack interest in studying this subject. Daily experience of dealing and interacting with students revealed that the Malaysian Studies have been given less priority by most students. As a result, most students gained low marks for this subject which simultaneously affects their academic cumulative grade points. Extensive past studies suggest that there is a close relationship between students' attitudes towards academic subject and their overall achievement (Erdogan, Bayram, \&Deniz, 2008; Konting, 1990). Literature review on this area reveals that there are two main contributing factors to students' academic achievement that are psychological and sociological factors. Psychological factors refer to the internal elements of individual including emotional and cognitive domains, whereas sociological factors refer to external factors such as socio-environment and friendship. However, both factors are inter-related and dependable. Most past studies tended to discuss the subject in a specific context. For instance, a study of academic achievement carried out by Ariffin (2007) focused on individual's learning style and how it affects his/her academic achievement. Although learning style has a close link with a person's personality and intellectual capabilities, the selection of learning styles is also influenced by environmental factors such as educational support provided by peers and teachers. Although previous studies found that there is a positive relationship between student's interest in academic subject and its performance (Arham, Mesir\&Mohammad, 2006; Zainudinet. al., 2007), classroom environment and their existing knowledge on the particular subjects also play major roles (Rhoda et. al., 2011). According to Popham(2005), students' attitudes or interests should be enormously important to educators, because affective dispositions are powerful predictors of students' subsequent behaviour. In a related study, Erdogan, Bayram, Deniz (2008) found that there is a positive relationship between students' attitudes towards modern learning technologies and their academic achievement. Academic achievement increases with the use of modern technologies positively. There is a strong association between individuals' attitudes towards education and their academic performance and commitment. Students who have negative attitudes towards education activities are found to exhibit challenging behaviour including anti-social and off-task behaviour (Awang, Jindal-Snape\& Barber, 2013). Ming, Ling and Jaafar (2011) found that streaming in education has a close relationship with students' academic achievement. They also found that students from science classes are more positive about academic performance compared to other students. It should be noted that the current study was carried out in Malaysia where most students are streamed according to their academic achievement. Previous research revealed that there is a link between academic achievement and socio-economic status (Ghazali, 2008). Living in poor and slum areas are found to contribute to the low academic achievement among students. Most low achievers also are from poor families (Farooq, Chaundhry \& Berhanu, 2011).

\section{Objectives of the Study}

This study investigated university students' attitudes towards nationhood and citizenship education in Malaysia. Particularly, the study examined the students' attitudes towards nationhood according to genders, ethnicity, origins and language used.

\section{Methodology}

The study employed the survey method as it is an effective approach to analyse large samples (Konting, 1990).It also allows respondents to indicate their standpoint without being influenced by others (Konting, 1999; Ghaffar, 1999). The respondents were asked to respond to six-point Likert-scale questionnaires where the score of six represents the highest level of agreement, whereas one represents the strongest disagreement. Questionnaire contains two sections that are demographic of respondents and student's attitude items. The questions were designed based on literature on past studies in this area (Kerr, 2005). The questions were then developed and piloted in order to validate the questionnaire. The pilot study was carried out in one of the Malaysian universities. It involved100 university students where Cronbach Alpha for all items exceeded0.84,which indicates that they are reliable and valid. The actual survey was conducted after the approval and consent were obtained from universities and respondents. In this study, a number of 839 students and 16 lecturers from 10 universities in Malaysia were randomly selected. Data collected was then analysed using SPSS by focusing on the descriptive statistics. 


\section{Results and Discussion}

Overall data shows that students outnumbered the lecturers in this study. Table 1 shows distribution of respondents according to the roles.

Table 1. Demographic of respondents, by ethnicity and age groups

\begin{tabular}{llcc}
\hline & Aspect & Lecturers & Students \\
\hline Ethnicity & Malay & $87 \%(\mathrm{n}=14)$ & $53 \%(\mathrm{n}=442)$ \\
& Chinese & $13 \%(\mathrm{n}=2)$ & $30 \%(\mathrm{n}=253)$ \\
Indian & 0 & $14 \%(\mathrm{n}=116)$ \\
Ege groups & Eurasia & 0 & $1 \%(\mathrm{n}=6)$ \\
& Less than 20 years & 0 & $29 \%(\mathrm{n}=246)$ \\
$20-22$ years & 0 & $45 \%(\mathrm{n}=377)$ \\
$25-29$ years & $19 \%(\mathrm{n}=3)$ & $2 \%(\mathrm{n}=11)$ \\
& $30-34$ years & $31 \%(\mathrm{n}=5)$ & 0 \\
& $35-39$ years & $25 \%(\mathrm{n}=4)$ & 0 \\
& $40-44$ years & $19 \%(\mathrm{n}=3)$ & 0 \\
& More than 44 years & $6 \%(\mathrm{n}=1)$ & 0 \\
\hline
\end{tabular}

The majority of students were Malay, followed by Chinese, Indian and other ethnics such as natives and Eurasia. The majority of lecturers participated in this study were Malay. Only two Chinese lectures involved in this study. Result shows that most students are at the age of 20-25 years, whereas the majority of lecturers are 30-39 years old. Nearly one-third of students are less than 20 years old. Detailed analyses on respondents' profile are presented below.

\subsection{Students' Profiles}

The majority of students are from urban areas and most of them have passed the Malaysian Certificate of Education examination. Nearly one-third of them had a diploma in various field of study. Most students in this study reported that they used Malay language as a medium and $42 \%$ used English in nationhood education. The majority of students participated in study obtained excellent grades where $46 \%$ obtained grade A and $33 \%$ obtained grade B for nationhood education subject.

Table 2. Students' profiles

\begin{tabular}{|c|c|c|c|}
\hline Items & & $\mathrm{n}$ & $\%$ \\
\hline \multirow[t]{3}{*}{ Origin } & Urban & 559 & 66.6 \\
\hline & Rural & 173 & 20.6 \\
\hline & Suburban & 107 & 12.8 \\
\hline \multirow{3}{*}{$\begin{array}{l}\text { Intermediate Language in } \\
\text { Malaysian Studies }\end{array}$} & Malay & 443 & 52.8 \\
\hline & English & 349 & 41.6 \\
\hline & Bilingual & 47 & 5.6 \\
\hline \multirow{6}{*}{$\begin{array}{l}\text { Achievements in Malaysian } \\
\text { Studies (grade) }\end{array}$} & A (excellent) & 384 & 45.8 \\
\hline & B (good) & 276 & 32.9 \\
\hline & $\mathrm{C}$ (fair) & 71 & 8.5 \\
\hline & Passed & 104 & 12.4 \\
\hline & Failed & 1 & 0.1 \\
\hline & No information & 3 & 0.4 \\
\hline
\end{tabular}




\subsection{Lecturers' Profiles}

Most of lecturers participated in this study were identified to be Malay. Most of them have a master's degree. This is consistent with the national higher education policy which is highly concerned about the performance and quality of the lecturers who teach. The majority of lecturers were at the age of $30-34$ years which were Malay and Chinese who had experience in teaching Malaysian Studies more than 5 years.

Table 3 shows that there were three specializations of lecturers involved in this study. Data showed that $43.8 \%$ were specialized in Social Sciences including Security Analysis \& Strategy, Public Administration, Political Science, Social Science, Sociology \& Anthropology and political Syari'iyyah (Islamic law); whereas 31.3\% specialized in Educational Studies.

Table 3. Lecturers' profiles

\begin{tabular}{llll}
\hline Item & & $\mathrm{n}$ & $\%$ \\
\hline \multirow{2}{*}{ Qualification } & Master Degree & 14 & 87.5 \\
& Degree & 2 & 12.5 \\
& $1-4$ years & 2 & 87.5 \\
Teaching Experience & $5-9$ years & 8 & 12.5 \\
& $10-14$ years & 4 & 12.5 \\
& More than 15 years & 2 & 50 \\
Teaching Experience of & $1-4$ years & 6 & 25 \\
Malaysian Studies & M-9 years & 8 & 12.5 \\
& More than 10 years & 2 & 37.5 \\
Specialization & Social Science & 7 & 43.8 \\
& Communication and Language & 4 & 25 \\
& Education & 5 & 31.3 \\
\hline
\end{tabular}

\subsection{Students'Academic Achievement}

Table 4 shows that the majority of the Malaysian Studies classes were conducted in Malay language and English Language with $52.8 \%$ and $41.6 \%$ respectively. Further analysis revealed that the A grade was the highest achievement by the students and followed by B grade.

Table 4. Language used and achievement

\begin{tabular}{|c|c|c|c|c|}
\hline Items & & Grade & $\mathrm{n}$ & $\%$ \\
\hline \multirow{6}{*}{$\begin{array}{l}\text { Achievements } \\
\text { Malaysian } \\
\text { (grade) }\end{array}$} & \multirow{6}{*}{$\begin{array}{r}\text { in } \\
\text { Studies }\end{array}$} & A & 384 & 45.8 \\
\hline & & B & 276 & 32.9 \\
\hline & & $\mathrm{C}$ & 71 & 8.5 \\
\hline & & Passed & 104 & 12.4 \\
\hline & & Failed & 1 & 0.1 \\
\hline & & No information & 3 & 0.4 \\
\hline
\end{tabular}

\subsection{Student's Attitudes towards Nationhood Education}

Students agree that by attending every class will help them to master Malaysian Studies, but according to the lecturers, students usually did not like to attend classes and were not punctual for the class. Accordingly, this attitude will affect the ability of mastering the subject. There is insufficient narrative data in this study to explore students' experience in learning that subject. However, past studies in learning motivation shows that several factors that motivate students to engage in lesson actively. For instance, Ahmad et al. (2013) found teachers' 
creativity and competency in using textbooks will encourage students' participation in classroom activities. Another study found that positive school ethos and good rapport with teachers are associated with positive behaviour in students (Awang et al, 2013). Past empirical study also demonstrated that joyful learning atmosphere is necessary to attract student attention and commitment in learning (Jablon \& Wilkinson, 2006; Wei, Hung, Lee $\&$ Chen, 2011). Results of the current study revealed that most students are very fond of the lecturers who were adept at organizing fun activities in class. This statement was also approved by the lecturers. They felt that the use of teaching aids not only strengthen the students' understanding of related concepts, but also provide an effective and fun learning. Unfortunately, students claimed, most of the lecturers do not use teaching aids during the teaching process, thus reducing the interest of students in the subject and consequently the students assume that the contents of Malaysian studies are uninteresting. The use of modern technology including robotic technology (Wei, Hung, Lee \& Chen, 2011) and computer technology (Jablon \& Wilkinson, 2006) are found to be effective strategies for promoting students' engagement in learning academic subjects. According to the lectures in this study, students respond well if they have fun activities during the lesson. Such activities assist them in attracting students' attention, and also the students would pose more questions to the lecturer. However, it is still unclear in this study what makes students enjoy in learning Nationhood Education. Therefore, an in-depth study exploring students' aspiration on joyful learning is needed.

Generally, students who prepare early and revise often usually obtain good results. However, according to the lecturers, students who did not prepare early, did not review and write notes of the subject may think that Malaysian studies is not an important subject.

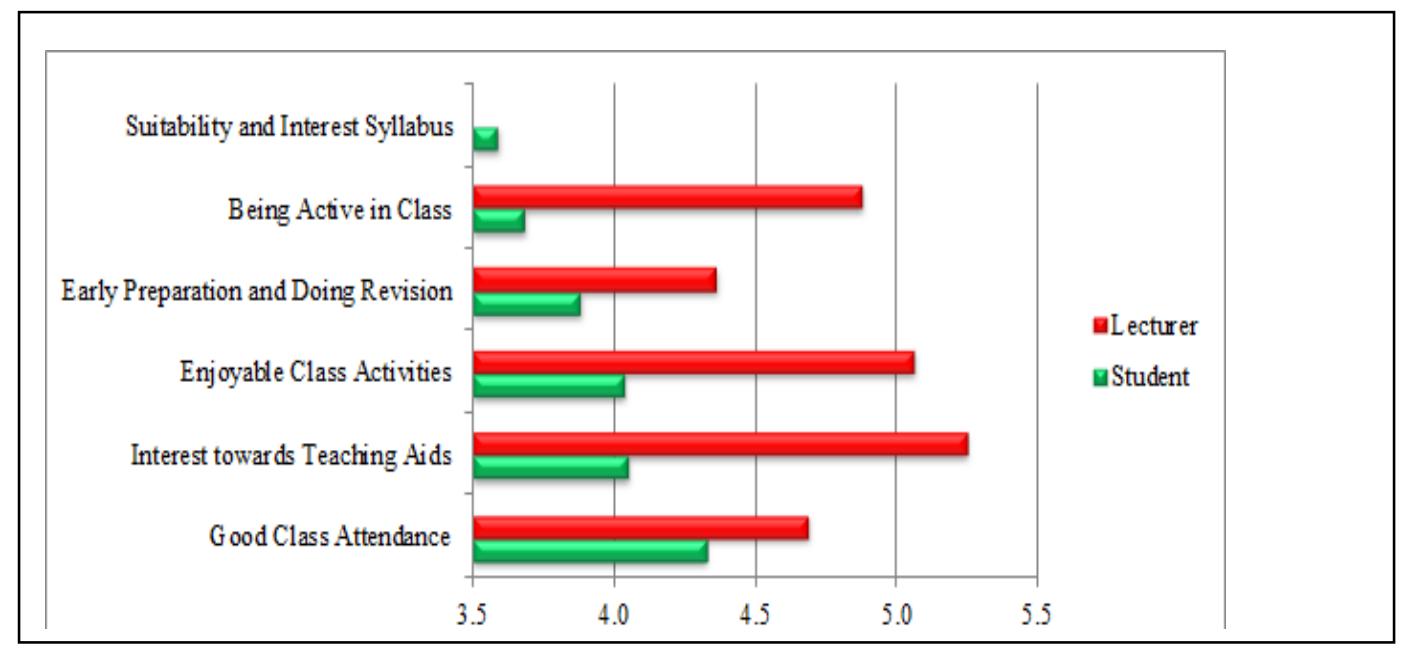

Figure 1. Comparison of Mean Score regarding Students' Attitude.

Figure 1 shows that ineffective and uninteresting teaching methods are the main causes that influence students' interest in Malaysian Studies. The teaching process in classroom should involve two parties between teacher and student. If the teachers only use syllabus, which emphasizes process over aspects of the history of the appreciation and application of two-way interaction, it can cause this loss of focus. In consequence, students will lose interest and consider the subject of history as a burdening subject (Long, 1982). The results show that only around $70 \%$ of respondents agree about the syllabus and activities in Malaysian studies.

Due to lack of interest in learning Malaysian studies, most of the respondents were not active in class and did not perform revision and preparation before attending the class.

This can be seen based on the percentage above which are $66.9 \%, 58.9 \%, 60.1 \%$ and $57.4 \%$. It has happened because respondents always underestimate the value of the subject. Things like this may occur as a result of the attitudes of respondents disdainful of Studies in Malaysia itself. To them, Malaysian Studies is not essential and easy to pass compared to other subjects, as Malaysian Studies subject is more into historical issues and in their view it is boring and uninteresting.

Respondents may not be aware or forget that without a past history then there is development today. History should be studied and understood so that we all will not make the same mistake in the past, such as being colonized by other ethnicity. 
Therefore, educators may manipulate the medium to fit the latest technologies and can be accessed at any time (Brandenburg \& Carroll, 1995) as it is important to attract students to the history of the subject.

\subsection{Students' Attitude towards Malaysian Studies}

Table 6. T-test of student attitude based on gender

\begin{tabular}{llll}
\hline Items & Mean difference & $\mathrm{t}$ & $\mathrm{p}$-value \\
\hline Attend classes in a timely manner & 0.080 & 0.868 & 0.386 \\
Love to attend every class & 0.208 & -2.397 & $0.017^{*}$ \\
Interest towards teaching aids & 0.081 & -0.884 & 0.377 \\
Suitability and interest syllabus & 0.005 & -0.057 & 0.954 \\
Enjoyable class activities & 0.013 & -0.140 & 0.888 \\
Being active in class & 0.134 & -1.459 & 0.145 \\
Read additional material & 0.203 & -2.177 & $0.030^{*}$ \\
Doing revision & 0.070 & -0.731 & 0.465 \\
Always make own note & 0.024 & -0.257 & 0.797 \\
Early preparation & 0.117 & -1.207 & 0.228 \\
\hline
\end{tabular}

*Significant level at 0.05

Results indicate that there are no significant differences between genders with regards to the most items except for the item of love to attend every class and read additional material. Descriptive data on these two items revealed that female students are more positive on attending lecture for nationhood education subject. Female students are more likely to read additional material relating to nationhood education.

Table 7. ANOVA comparison of students' attitudes based on ethnicity, origin, and intermediate language in Malaysian studies

\begin{tabular}{lllllll}
\hline \multirow{2}{*}{ Items } & \multicolumn{2}{l}{ Ethnicity } & \multicolumn{3}{c}{ Origin } & \multicolumn{3}{c}{ Language used } \\
\cline { 2 - 7 } & F-ratio & p-value & F-ratio & p-value & F-ratio & p-value \\
\hline Attend classes in a timely manner & 23.772 & $0.000^{*}$ & 5.585 & $0.040^{*}$ & 33.481 & $0.000^{*}$ \\
Love to attend every class & 2.319 & 0.074 & 0.595 & 0.550 & 7.192 & $0.001^{*}$ \\
Interest towards teaching aids & 21.913 & $0.000^{*}$ & 3.803 & $0.023^{*}$ & 20.567 & $0.000^{*}$ \\
Suitability and interest syllabus & 13.292 & $0.000^{*}$ & 3.026 & $0.049^{*}$ & 27.041 & $0.000^{*}$ \\
Enjoyable class activities & 19.957 & $0.000^{*}$ & 3.581 & $0.028^{*}$ & 16.501 & $0.000^{*}$ \\
Being active in class & 17.530 & $0.000^{*}$ & 4.258 & $0.014^{*}$ & 25.86 & $0.000^{*}$ \\
Read additional material & 15.861 & $0.000^{*}$ & 6.947 & $0.001^{*}$ & 18.759 & $0.000^{*}$ \\
Doing revision & 15.723 & $0.000^{*}$ & 6.260 & $0.002^{*}$ & 22.974 & $0.000^{*}$ \\
Always make own note & 15.564 & $0.000^{*}$ & 7.699 & $0.000^{*}$ & 24.84 & $0.000^{*}$ \\
Early preparation & 13.440 & $0.000^{*}$ & 2.648 & $0.071^{*}$ & 12.885 & $0.000^{*}$ \\
\hline
\end{tabular}

*Significant level at 0.05

Analysis of the data using one-way ANOVA technique revealed that the difference was significant at the 0.05 level among ethnic groups on all items except 'love to attend every class'. The analysis also showed a significant result for rural, urban and suburban students' towards except love to attend every class followed by early preparation. However, there was no significant difference among intermediate language in Malaysian Studies. 


\section{Implication}

The research shows that the attitude of students will affect their achievement in learning Malaysian studies. The discussion also shows that student's attitude also affects the classroom learning styles. Therefore, students should be exposed to an interesting environment in class. Comfortable learning environment will create a good attitude and reduce the bad attitudes (Azizi, Halimah \& Faizah, 2011). Hence, the lecturers need to identify the real attitude of students and thus be able to find a way to help and attract students for this subject.

\section{Conclusion}

The current study has highlighted the significant association between students' achievements and their attitudes towards academic subject. Although, overall data suggest that most participants in this has a quite positive attitudes towards Malaysian Studies (one of the nationhood education subjects), there is a big gap between lecturers' and students' perceptions towards how to attract students engagement in Malaysian Study lesson. Results of this study indicated that most students were not active in class activities, poor attendance and exhibited a lack of motivation to study the subject. These might be due to the differences of perceptions between them regarding the most effective strategies. Most lecturers believe that the use of teaching aids would be able to attract students' attentions, however most students highlighted the importance of good class attendance as the most effective way. Differences also occurred between genders as female students are more likely to read more materials. There is no narrative data to explain why male students have a lack of interest to read additional materials. As students from different genders have different preferences, the use of technological-teaching based instruments such as computer technology and internet are crucial. Similarities can be seen through this study that both parties have agreed that the pleasant and enjoyable activities in class influence students' achievement. Therefore, lecturers' creativity and their competency in pedagogical content knowledge are imperative. Teaching and learning for this subject are supposed to be more meaningful if the lecturers integrate many elements either in the subject content or approaches. Indeed, many lecturers in this study pointed out that the effective use of teaching aids motivate students and change their attitude towards learning Malaysian Studies. As students' achievements are associated with their attendance and participation in class activities, organising this academic subject in an attractive manner is vital. Overall, the current study recommends that the lectures should build up an excellent rapport with students as creates the classroom attractive and enjoyable platform for learning Malaysian Studies.

\section{Reference}

Abdullah, A., Mesir, B., \& Mohamad, A. M. (2006). Contributing Factors to Academic Excellence among Students in University of Technology Malaysia. In National Student Development Conference (NASDEC), 2006, 8-9 August 2006, Kuala Lumpur, Malaysia.

Ahmad, A. R., Rahim, A., \& Seman, A. A. (2013). Active learning through History Subject towards Racial Unity in Malaysia. The Social Science, 8(1), 19-24.

Ariffin, K. (2007). The relationship between learning styles and academic achievements in the subject of Electromagnetic among fist degree students in UTHM. PSP's Research Digest, 17-21.

Awang, M. M., Ahmad, A. R., Wahab, J. L. A., \& Mamat, N. (2013). Effective teaching strategies to encourage learning behaviour. IOSR Journal of Humanities and Social Sciences, 8(2), 35-40. http://dx.doi.org/10.9790/0837-0823540

Awang, M. M., Jindal-Snape, D., \& Barber, T. (2013). A Documentary Analysis of the Government's Circulars on Positive Behaviour Enhancement Strategies. Asian Social Science, 9(5), 203-208. http://dx.doi.org/10.5539/ass.v9n5p203

Azizi, Y., Halimah, M., \& Faizah, Idris. (2011). Persepsi Pelajarterhadap Perlakuan Agresif yang Berlaku di Lima Buah Sekolah Menengah di Kawasan Bandar Johor Bahru (Students' Perception on Aggressive Behaviour in Five Secondary Schools in Urban Areas of Johor Bahru). Journal of Educational Psychology and Counseling. ISSN: 2231-735X. 1-24.

Brandenburg, A. M., \& Carroll, M. S. (1995). Your place or mine? The effect of place creation on environmental values and landscape meanings. Society and Natural Resources, 8(5), 381-389. http://dx.doi.org/10.1080/08941929509380931

Da, W. C. (2007). Public and private higher education institutions in Malaysia: Competing, complimentary or crossbreeds as education providers. Kajian Malaysia, $X X V(1), 1-14$. 
Erdogan, Y., Bayram, S., \& Deniz, L. (2008). Factors that influence academic achievement and attitudes in web based education. International Journal of Instruction, 1(1), 31-48.

Farooq, M. S., Chaundhry, A. H., \& Berhanu, G. (2011). Factors Affecting Students' Quality of Academic Performance: A Case of Secondary School Level. Journal of Quality and Technology Management, VII(II), $1-14$.

Ghaffar, M. N. A. (1999). Educational Research. Skudai: Penerbit UTM.

Ghazali, S. N. (2008). Learner Background and their Attitudes towards Studying Literature. Malaysian Journal of ELT Research, 4, 1-17.

Jablon, J. R., \& Wilkinson, M. (2006). Using Engagement Strategis to Facilitate Children's learning and Success. Young Children on the Web, 1-5.

Kerr, D. (2005). Citizenship Education in England - Listening to Young People: New Insights from the Citizenship Education Longitudinal Study. International Journal of Citizenship and Teacher Education, 1(1), 74-96.

Konting, M. M. (1990). Educational Research Methods. Kuala Lumpur: Dewan Bahasa \& Pustaka.

Long, A. (1982). Pedagogy - Teaching Methods. Kuala Lumpur: Penerbit Fajar Bakti.

McKenzie, H. (1993). Citizenship Education in Canada. BP-326E. Retrieved June 20, 2013, from http://publications.gc.ca/Collection-R/LoPBdP/BP/bp326-e.htm\#B

Ming, T. S., Ling, T. S., \& Jaafar, N. M. (2011). Attitudes and Motivation of Malaysian Secondary Students towards learning English as a Second Language. The Southeast Asian Journal of English Language Studies, $17(1), 40-54$.

Popham, W. J. (2005). Students' Attitudes Count. Educational Leadership. Educational Leadership, 84-85.

Rhoda D. B., Muhammad Imran, Y., Mohd. Mahzan, A., \& Asif, N. R. (2011). The effect of prior knowledge in understanding chemistry concepts by senior secondary school students. International Journal of Academic Research, 3(2), 607-611.

Wei, C. W., Hung, I. C., Lee, L., \& Chen, N. S. (2011). A Joyful Classroom Learning System with Robot Learning Companion for Children to Learn Mathematics Multiplication. TOJET: The Turkish Online Journal of Educational technology, 10(2), 11-23.

Zainudin, H., Suhashila, T. L., M. Najib, A. G., \& Hamdan, S. (2007). The use of teaching aids among pre-service teachers. Seminar on Educational Research Batu Lintang Teaching Institute Malaysia, 1-9.

\section{Copyrights}

Copyright for this article is retained by the author(s), with first publication rights granted to the journal.

This is an open-access article distributed under the terms and conditions of the Creative Commons Attribution license (http://creativecommons.org/licenses/by/3.0/). 